medRxiv preprint doi: https://doi.org/10.1101/2020.09.04.20188243; this version posted September 7, 2020. The copyright holder for this preprint

(which was not certified by peer review) is the author/funder, who has granted medRxiv a license to display the preprint in perpetuity.

It is made available under a CC-BY-ND 4.0 International license.

\title{
Lack of evidence for association of UQCRC1 with Parkinson's disease in Europeans
}

Konstantin Senkevich ${ }^{1,2}$ MD, PhD, Sara Bandres-Ciga ${ }^{3} \mathrm{PhD}$, Ziv Gan-Or ${ }^{1,2,4}$ MD, PhD, Lynne Krohn ${ }^{1,4} \mathrm{MSc}$, on behalf of the International Parkinson's Disease Genomics Consortium (IPDGC)

Affiliations:

${ }^{1}$ Montreal Neurological Institute, McGill University, Montréal, QC, H3A 1A1, Canada

${ }^{2}$ Department of Neurology and neurosurgery, McGill University, Montréal, QC, H3A 0G4, Canada, Canada

${ }^{3}$ Molecular Genetics Section, Laboratory of Neurogenetics, NIA, NIH, Bethesda, MD, USA

${ }^{4}$ Department of Human Genetics, McGill University, Montréal, QC, H3A 1A1, Canada

\section{Corresponding author:}

Konstantin Senkevich

Montreal Neurological Institute,

McGill University

1033 Pine Avenue, West,

Ludmer Pavilion, room 308-309

Montreal, QC, H3A 1A1,

Phone: +1-438-979-5052

e-mail: konstantin.senkevich@mcgill.ca 


\begin{abstract}
Recently, a novel variant p.Y314S in UQCRC1 has been implicated as pathogenic in Parkinson's disease (PD). In the current study, we aimed to examine the association of UQCRC1 with PD in large cohorts of European origin. We examined common and rare genetic variation in UQCRC1 using genome-wide association study data from the International Parkinson Disease Genomics Consortium (IPDGC), including 14,671 cases and 17,667 controls, and whole-genome sequencing data from the Accelerating Medicines Partnership - Parkinson's disease initiative (AMP-PD), including 1,647 PD patients and 1,050 controls. No common variants were consistently associated with PD, and a variety of burden analyses did not reveal an association between rare variants in $U Q C R C 1$ and $\mathrm{PD}$. Therefore, our results do not support a major role for UQCRC1 in $\mathrm{PD}$ in the European population, and additional studies in other populations are warranted.
\end{abstract}

Keywords: Parkinson disease; genetics; UQCRC1; 
medRxiv preprint doi: https://doi.org/10.1101/2020.09.04.20188243; this version posted September 7, 2020. The copyright holder for this preprint (which was not certified by peer review) is the author/funder, who has granted medRxiv a license to display the preprint in perpetuity.

It is made available under a CC-BY-ND 4.0 International license.

\section{Introduction}

The genetics of Parkinson's disease (PD) has been extensively studied over the last 20 years

(Bandres-Ciga et al., 2020). A recent genome-wide association study (GWAS) identified 90 independent risk variants (Nalls et al., 2019); however, these variants explain less than $50 \%$ of the heritability of PD (Nalls et al., 2019), suggesting that other, unknown common and rare genetic variants affect the risk of PD. A novel variant p.Y314S in UQCRC1 encoding the ubiquinol $\square$ cytochrome c reductase core protein (UQCRC1) has been recently identified in five Taiwanese family members with parkinsonism by whole-exome sequencing (Lin et al., 2019). UQCRC1 is a mitochondrial protein and part of the respiratory chain III complex (Hoffman et al., 1993), which may play a role in mitochondrial respiration (Lin et al., 2019; Shan et al., 2019).

The purpose of this work is to examine the role of $U Q C R C 1$ in a large-scale European PD population utilizing GWAS and whole-genome sequencing (WGS) data from the International Parkinson Disease Genomics Consortium (IPDGC) and Accelerating Medicines Partnership - Parkinson's disease (AMP-PD) initiative.

\section{Methods}

The study populations included 14,671 PD patients and 17,667 controls from IPDGC, and 1,647 PD patients and 1,050 controls from AMP-PD (https://amp-pd.org/). Quality control of IPDGC GWAS data was performed on both individual and variant levels as previously described (Nalls et al., 2019). Similar quality control procedures were performed in the AMP-PD WGS data, as described by AMP-PD (https://amp-pd.org/whole-genome-data). We extracted UQCRC1 genotyping data from both datasets using gene coordinates determined by UQCRC1 position (+/100kb): hg19: chr3:48,536,432-48,747,098; hg38: chr3:48,499,002-48,709,646. We utilized ANNOVAR (Wang et al., 2010) to annotate both data sets. PLINK 1.9 (Chang et al., 2015) was used for logistic regression (adjusted for age, sex and first 10 principal components) to study the association between common $U Q C R C 1$ variants (with minor allele frequency $[\mathrm{MAF}]>0.01$ ) and 
PD in the IPDGC cohort. In the AMP-PD cohort, to study the burden of rare variants (defined as variants with MAF $<0.03$ in the current data), a variety of methods were applied, including sequence Kernel association test and its optimized version (SKAT and SKAT-O), combined multivariate and collapsing (CMC), Zeggini and Madsen-Browning tests, as a part of the Rvtest package (Zhan et al., 2016). Bonferroni correction was applied to correct for multiple comparisons. All code used in the current study is available at our GitHub at https://github.com/ipdgc/IPDGC-Trainees/blob/master/UQCRC1_IPDGC_trainee.md.

\section{Results}

Using the IPDGC GWAS data, we identified 140 common variants in the selected region (Figure 1). None of the common variants annotated to UQCRC1 were associated with PD (Supplementary Table 1). In the AMP-PD WGS data we identified 94 variants with MAF $<0.03$ within or close to UQCRC1 (Supplementary Table 2), including 9 nonsynonymous variants (Supplementary Table 2). We performed burden tests for three categories of variants: 1) all rare variants, 2) all rare coding variants and 3) all rare nonsynonymous variants. None of the burden tests showed association between rare UQCRC1 variants and PD (Table 1). In both cohorts, we did not find the UQCRC1 p.Y314S variant described in the original paper (Lin et al., 2019).

\section{Discussion}

In the current study, we performed a comprehensive analysis of common and rare variants in UQCRC1 using GWAS and WGS data from large cohorts of PD patients and controls.

In the original study in which $U Q C R C 1$ variants were implicated, the authors described a family in which 5 carriers of UQCRC1 p.Y314S had late-onset parkinsonism and axonal type sensorimotor polyneuropathy (Lin et al., 2019). Recent replication study in an eastern Chinese population did not reveal association between UQCRC1 and PD (Lin et al., 2020).

It is possible that this variant is associated with a specific form of atypical parkinsonism, but not with typical PD. It has been shown that a number of genes previously reported as PD- 
associated (such as DNAJC13, UCHL1, HTRA2, GIGYF2, and EIF4G1) do not play a role in PD and thus, should not be regarded as PD genes (Foo et al., 2014; Krüger et al., 2011; Lesage et al., 2010; Saini et al., 2020). Furthermore, other genes (e.g. ATP13A2, FBXO7) that are associated with atypical forms of parkinsonism are often cited as PD-associated genes (Dehay et al., 2012; Deng et al., 2015; Weissbach et al., 2019). It is important to properly define which genes are involved in typical PD and which genes are not, particularly in the era of targeted drug development.

Overall, we did not find any evidence to support an important role for $U Q C R C 1$ in PD patients of European origin. However, additional studies in other populations are required to further study the potential role of UQCRC1 in PD, and we cannot rule out the possibility that very rare, specific UQCRC1 variants are associated with $\mathrm{PD}$ or with atypical forms of parkinsonism. 
medRxiv preprint doi: https://doi.org/10.1101/2020.09.04.20188243; this version posted September 7, 2020. The copyright holder for this preprint (which was not certified by peer review) is the author/funder, who has granted medRxiv a license to display the preprint in perpetuity.

It is made available under a CC-BY-ND 4.0 International license.

\section{Acknowledgements}

We thank the participants for contributing to the study. We would like to also thank all members of the International Parkinson Disease Genomics Consortium (IPDGC). For a complete overview of members, acknowledgements and funding, please see http://pdgenetics.org/partners. This work was financially supported by grants from the Michael J. Fox Foundation, the Canadian Consortium on Neurodegeneration in Aging (CCNA), the Canada First Research Excellence Fund (CFREF), awarded to McGill University for the Healthy Brains for Healthy Lives initiative (HBHL), and Parkinson Canada. This research was supported in part by the Intramural Research Program of the NIH, National institute on Aging. KS is supported by a post-doctoral fellowship from the Canada First Research Excellence Fund (CFREF), awarded to McGill University for the Healthy Brains for Healthy Lives initiative (HBHL). ZGO is supported by the Fonds de recherche du Québec - Santé (FRQS) Chercheurs-boursiers award, in collaboration with Parkinson Quebec, and by the Young Investigator Award by Parkinson Canada.

\section{Conflict of interests}

ZGO has received consulting fees from Lysosomal Therapeutics Inc., Idorsia, Prevail Therapeutics, Denali, Ono Therapeutics, Neuron23, Handl Therapeutics, Deerfield and Inception Sciences (now Ventus). None of these companies were involved in any parts of preparing, drafting and publishing this study. Other authors have no additional disclosures to report. 


\section{References}

Bandres-Ciga, S., Diez-Fairen, M., Kim, J.J., Singleton, A.B., 2020. Genetics of Parkinson's disease: An introspection of its journey towards precision medicine. Neurobiol Dis 137, 104782.

Chang, C.C., Chow, C.C., Tellier, L.C., Vattikuti, S., Purcell, S.M., Lee, J.J., 2015. Second-generation PLINK: rising to the challenge of larger and richer datasets. Gigascience 4, 7.

Dehay, B., Ramirez, A., Martinez-Vicente, M., Perier, C., Canron, M.-H., Doudnikoff, E., Vital, A., Vila, M., Klein, C., Bezard, E., 2012. Loss of P-type ATPase ATP13A2/PARK9 function induces general lysosomal deficiency and leads to Parkinson disease neurodegeneration. Proceedings of the National Academy of Sciences 109(24), 9611-9616.

Deng, H., Wu, Y., Jankovic, J., 2015. The EIF $4 \mathrm{G} 1$ gene and Parkinson's disease. Acta Neurologica Scandinavica 132(2), 73-78.

Foo, J.N., Liany, H., Tan, L.C., Au, W.-L., Prakash, K.-M., Liu, J., Tan, E.-K., 2014. DNAJ mutations are rare in Chinese Parkinson's disease patients and controls. Neurobiology of aging 35(4), 935. e931-935. e932. Hoffman, G., Lee, S., Christiano, A., Chung-Honet, L., Cheng, W., Katchman, S., Uitto, J., Greenspan, D., 1993. Complete coding sequence, intron/exon organization, and chromosomal location of the gene for the core I protein of human ubiquinol-cytochrome c reductase. Journal of Biological Chemistry 268(28), 21113-21119.

Krüger, R., Sharma, M., Riess, O., Gasser, T., Van Broeckhoven, C., Theuns, J., Aasly, J., Annesi, G., Bentivoglio, A.R., Brice, A., 2011. A large-scale genetic association study to evaluate the contribution of Omi/HtrA2 (PARK13) to Parkinson's disease. Neurobiology of aging 32(3), 548. e549-548. e518.

Lesage, S., Condroyer, C., Lohman, E., Troiano, A., Tison, F., Viallet, F., Damier, P., Tranchant, C., Vidhaillet, M., Ouvrard-Hernandez, A.-M., 2010. Follow-up study of the GIGYF2 gene in French families with Parkinson's disease. Neurobiology of Aging 31(6), 1069-1071.

Lin, C.H., Chen, P.L., Tai, C.H., Lin, H.I., Chen, C.S., Chen, M.L., Wu, R.M., 2019. A clinical and genetic study of early-onset and familial parkinsonism in taiwan: An integrated approach combining gene dosage analysis and next-generation sequencing. Mov Disord 34(4), 506-515.

Lin, Z.H., Zheng, R., Ruan, Y., Gao, T., Jin, C.Y., Xue, N.J., Dong, J.X., Yan, Y.P., Tian, J., Pu, J.L., Zhang, B.R., 2020. The lack of association between ubiquinol-cytochrome $c$ reductase core protein I (UQCRC1) variants and Parkinson's disease in an eastern Chinese population. CNS Neurosci Ther 26(9), 990-992. Nalls, M.A., Blauwendraat, C., Vallerga, C.L., Heilbron, K., Bandres-Ciga, S., Chang, D., Tan, M., Kia, D.A., Noyce, A.J., Xue, A., Bras, J., Young, E., von Coelln, R., Simon-Sanchez, J., Schulte, C., Sharma, M., Krohn, L., Pihlstrom, L., Siitonen, A., Iwaki, H., Leonard, H., Faghri, F., Gibbs, J.R., Hernandez, D.G., Scholz, S.W., Botia, J.A., Martinez, M., Corvol, J.C., Lesage, S., Jankovic, J., Shulman, L.M., Sutherland, M., Tienari, P., Majamaa, K., Toft, M., Andreassen, O.A., Bangale, T., Brice, A., Yang, J., Gan-Or, Z., Gasser, T., Heutink, P., Shulman, J.M., Wood, N.W., Hinds, D.A., Hardy, J.A., Morris, H.R., Gratten, J., Visscher, P.M., Graham, R.R., Singleton, A.B., andMe Research, T., System Genomics of Parkinson's Disease, C., International Parkinson's Disease Genomics, C., 2019. Identification of novel risk loci, causal insights, and heritable risk for Parkinson's disease: a meta-analysis of genome-wide association studies. Lancet Neurol 18(12), 1091-1102.

Saini, P., Rudakou, U., Yu, E., Ruskey, J., Asayesh, F., Laurent, S., Spiegelman, D., Fahn, S., Waters, C., Monchi, O., 2020. Association of DNAJC13, UCHL1, HTRA2, GIGYF2, and EIF4G1 with Parkinson's Disease. medRxiv.

Shan, W., Li, J., Xu, W., Li, H., Zuo, Z., 2019. Critical role of UQCRC1 in embryo survival, brain ischemic tolerance and normal cognition in mice. Cellular and Molecular Life Sciences 76(7), 1381-1396.

Wang, K., Li, M., Hakonarson, H., 2010. ANNOVAR: functional annotation of genetic variants from highthroughput sequencing data. Nucleic acids research 38(16), e164-e164.

Weissbach, A., Wittke, C., Kasten, M., Klein, C., 2019. 'Atypical'Parkinson's disease-genetic, International review of neurobiology. Elsevier, pp. 207-235.

Zhan, X., Hu, Y., Li, B., Abecasis, G.R., Liu, D.J., 2016. RVTESTS: an efficient and comprehensive tool for rare variant association analysis using sequence data. Bioinformatics 32(9), 1423-1426. 
medRxiv preprint doi: https://doi.org/10.1101/2020.09.04.20188243; this version posted September 7, 2020. The copyright holder for this preprint

(which was not certified by peer review) is the author/funder, who has granted medRxiv a license to display the preprint in perpetuity.

It is made available under a CC-BY-ND 4.0 International license.

Figure 1. LocusZoom plot of IPDGC GWAS summary statistics showing variants with MAF more than $1 \%$ near the UQCRC1 gene 
medRxiv preprint doi: https://doi.org/10.1101/2020.09.04.20188243; this version posted September 7, 2020. The copyright holder for this preprint (which was not certified by peer review) is the author/funder, who has granted medRxiv a license to display the preprint in perpetuity.

It is made available under a CC-BY-ND 4.0 International license .

Table 1. Burden tests for UQCRC1 in the AMP-PD cohort.

\begin{tabular}{|c|c|c|c|c|c|c|c|c|c|}
\hline \multirow[b]{2}{*}{$\begin{array}{l}\text { Burden } \\
\text { test }\end{array}$} & \multicolumn{3}{|c|}{ All variants } & \multicolumn{3}{|c|}{ Coding variants } & \multicolumn{3}{|c|}{ Nonsynonymous variants } \\
\hline & $\begin{array}{l}\text { Num } \\
\text { Var }\end{array}$ & $\begin{array}{l}\text { NumPolyV } \\
\text { ar }\end{array}$ & P-value & $\begin{array}{l}\text { Num } \\
\text { Var }\end{array}$ & $\begin{array}{l}\text { NumPoly } \\
\text { Var }\end{array}$ & P-value & NumVar & $\begin{array}{l}\text { NumPoly } \\
\text { Var }\end{array}$ & P-value \\
\hline Zeggini & 73 & 54 & 0.562 & 18 & 13 & 0.619 & 12 & 9 & 0.721 \\
\hline SKAT-O & 73 & 54 & 0.77 & 18 & 13 & 0.586 & 12 & 9 & 0.712 \\
\hline SKAT & 73 & 54 & 0.865 & 18 & 13 & 0.476 & 12 & 9 & 0.594 \\
\hline $\begin{array}{l}\text { Madson- } \\
\text { Browning }\end{array}$ & 73 & 54 & 0.487 & 18 & 13 & 0.046 & 12 & 9 & 0.109 \\
\hline $\mathrm{Fp}$ & 73 & 54 & 0.712 & 18 & 13 & 0.489 & 12 & 9 & 0.898 \\
\hline CMC & 73 & 54 & 0.596 & 18 & 13 & 0.629 & 12 & 9 & 0.731 \\
\hline
\end{tabular}

SKAT- sequence Kernel association test; SKAT-O - Sequence Kernel association test optimized version; CMC combined multivariate and collapsing; NumVar - number of variants; NumPolyVar - number of polymorphic genotypes; 
date: Tue Aug 11 16:36:45 2020

build: hg19

display range: chr3:48536431-48747098 [48536431-48747098]

hilite range: $0-0$ [0-0]

reference SNP: chr3:48586891

number of SNPs plotted: 266

min P-value: 4.6E-4 [chr3:48586891]

max P-value: 9.88E-1 [chr3:48536675] 